\title{
Contrastive Pragmatics in a Diachronic Perspective: Insights from Othello
}

\author{
Irma Taavitsainen \\ Professor Emerita, English Philology, University of Helsinki, Helsinki, \\ Finland \\ irma.taavitsainen@helsinki.fi \\ Matylda Wtodarczyk \\ Professor, Department of the History of the English Language, \\ Adam Mickiewicz University, Poznań, Poland \\ wmatylda@amu.edu.pl
}

\begin{abstract}
The paper provides an overview of the interface of contrastive and historical pragmatics and a case study of Othello's monologue. The emerging lines of development at the cross-roads of contrastive and historical pragmatics cover, in particular, speech acts, forms of discursive behaviour and stance. In the analysis, German, Swedish, Finnish and Polish translations from different periods are compared to show differences in the above-mentioned features. The illustrations are contextualised in order to show the discursive sensitivity of these linguistic items and their cross-linguistic diversity. The study reveals some tendencies and diachronic developments in translation strategies and underlines the need to include historical analyses in the realm of contrastive research.
\end{abstract}

\section{Keywords}

historical pragmatics - tertium comparationis - speech acts - terms of address Shakespeare's Othello 


\section{Historical and Contrastive Pragmatics}

The scope of pragmatics broadened to new areas in the 1980s, including contrastive pragmatics, an important and versatile field with its scope encompassing studies that compare, e.g. the realisation of speech acts, expressions of stance and forms of discursive behavior in various languages. Studies that probe into the historical dimension of these areas coincide with topics of historical pragmatics which springs off from pragmatics combined with historical linguistics and philology. In the 1980s, however, pragmatic studies on historical data were conducted under various labels. ${ }^{1}$ Topics of early studies that have proved important for historical pragmatics include politeness that has broadened to impoliteness and become a main trend; the politeness notion was first applied to Chaucer's texts at the interface of literary pragmatics (Sell 1985a and $1985 \mathrm{~b}$ ). Another much discussed topic is the relation between the written and the spoken modes (Österreicher and Koch 1985); the line continues with speech-related studies (e.g. Culpeper and Kytö 2010). The first extensive and more systematic presentation of the field under the label "historical pragmatics" was published in 1995 in the "inaugural" collective volume (ed. by Jucker) that contained a selection of 21 studies: those that were more philological were placed under the title "Pragmaphilology", while those more in line with historical linguistics were divided into "Diachronic form-to-function mapping" and "Diachronic function-to-form mapping". Some of the chapters took the historical sociolinguistics line, but all pertained to the broad view of pragmatics with contextual assessments including culture.

This paper deals with the emerging interface of contrastive pragmatics and historical pragmatics. Our contribution has two objectives. First, it will point out the importance of extending contrastive studies to historical data, and our analysis will also point out the possibility of conveying diachronic comparative studies between various time periods in one language. Second, it will provide

1 These terms include "sociohistorical linguistics", "diachronic lexical semantics", "Pragmatische Texttheorie" in an overview by Stein, who provides a synthesis of early historical pragmatic studies in the area in German historical linguistics in the late 1970 os and early 1980s, enumerating address systems, diachronic lexical semantics, speech acts and text-types as fields of interest $(1985: 347-351)$. Other pertinent terms include "sociohistorical pragmatics" “historical socio-pragmatics” (Kopytko 1995: 15; see Włodarczyk 2007: 8 for an overview of the terms used in the early 200os). 
a case study to demonstrate how contrastive historical pragmatics can find a further interface with translation studies. Our aims are in agreement with the journal policy: besides synchronic studies, the Editorial of the inaugural issue of the journal of Contrastive Pragmatics (2020: vii-viii) advocates an interest in the diachronic perspective overlapping with historical pragmatics and historical sociolinguistics; the present article responds to this call. Moreover, in their recent monograph, Kádár and House (2021) postulate that synchronic contrastive studies should be extended to include comparisons between spatially distant cultures.

At the beginning of the article, we briefly outline the scope of the interface between the two subfields of contrastive and historical pragmatics. We shall first discuss the realisation of speech acts (sAs) and then go over to stance expressions and forms of discursive behavior in interaction. ${ }^{2}$ Our empirical section can be situated between the contrastive and historical pragmatics. We shall also cross over to translation studies as the original text is in English and we discuss parallel sections that provide translations at different points of time in four different languages: German, Polish, Swedish and Finnish. Our analysis also contributes to diachronic comparative studies between various time periods of one language. We compare emotional outbursts, address terms and the realisation of speech acts in the four above-mentioned languages from their earliest renderings in those languages to recent translations of extracts from Shakespeare's Othello, one of the most important literary texts in Western culture. The interface between historical pragmatics and fiction seems to be attracting increasing attention in pragmatic studies, and our case study is also in accordance with this trend. At the end of our article, we shall discuss and draw some conclusions of the emerging lines of developments at the crossroads of contrastive and historical pragmatics.

\section{Tertium Comparationis}

Definitions of historical pragmatics vary according to two current branches of pragmatics. The definition in the inaugural volume (Jucker 1995 ed.) focused on language use over time and "communication in earlier periods" (Jacobs and Jucker 1995: 5). Another formulation more than a decade later gave historical pragmatics as "patterns of intentional human interaction (as determined by the conditions of society) of earlier periods, the developments of these patterns,

2 They may be more comparative than contrastive or simply treat similar topics in different languages, and we make no claim to completeness with our survey. 
and the general principles underlying such developments" (Jucker 2008: 895). ${ }^{3}$ The Mouton Handbook of Historical Pragmatics states that historical pragmatics pays "attention to meaning-making processes in past contexts to find out how meaning is negotiated and how more is conveyed than what is said" (Taavitsainen and Jucker 2010: 6). In contrast, the Anglo-American approach focuses on language change. Traugott (2008) defined historical pragmatics as a "usage-based approach to language change", and more recently she took "historical pragmatics to be the study of the linguistic contextual features that may lead to change, both semantic and morphosyntactic" (Traugott 2019: 25).

The division into two "schools of thought" was first discussed by Huang (2007: 4-5) and is still valid. It is obvious that Traugott's line is more in accordance with historical linguistics than the broad line of pragmatics reflected e.g. in the IPrA conferences. The dividing line according to geography does not hold, as there are several continental researchers who focus on linguistic processes like grammaticalisation, (inter)subjectification and pragmaticalisation; thus research questions would give a better indication of the line. Huang also mentions the terms component view and perspective view (from Verschueren 1999: 7,11$)$. Both enhance contextual analysis, but there is an essential difference in how context is defined: the narrow view takes language internal aspects into account, while the broad scope relies on the cultural context and external factors, trying to recover contemporaneous perspectives, conceptualisations, views and ideologies in its search for explanations for change; only the perspective view seems to be relevant to our present task. Studies that pertain to this interface apply a multilayered analytical grid on a scale from micro to macro context and language use as tied to its time and space with situational and cultural constraints (for context, see Duranti and Goodwin eds. 1992; van Dijk 2008; Blommaert 2005, Blommaert and Szabla 2018).

Pragmatics in general deals with communicative language use in context, and this definition serves well as the basis for contrastive pragmatics. It is a special field that focuses on the study of differences between conventions in written communication of various cultures (cf. Aijmer ed. 2009). The field is very closely related to comparative pragmatics and intercultural pragmatics (see Scollon \& Scollon 2001: 43-59). Several books and papers deal with these areas (e.g. House 2006 and 2016; Ogiermann 2009; Ogiermann and Spyridoula 2020; Derigner et al. 2015), and e.g. the aim of Kranich's book (2016) is to show pragmatic contrasts between English and German and how they are handled in English-German translations (e.g. House 2006 and 2016). Researchers who

3 Cf. Mey's definition of pragmatics as a cluster of related problems rather than as a welldelimited field of study (1998: 725). 
engage in the study of forms of discursive behavior more broadly often adopt an ethnographic perspective, clearly distinguishing between intercultural and contrastive pragmatics: "the contrastive research of datasets across different lingua-cultures allows us to engage in a bottom-up, contrastive pragmatic investigation, which is more rigorous and replicable in scope than what topdown inquiries, such as intercultural pragmatics, would provide" (Kádár and House 2019: 3; more on the study into ritual frames as an interface of contrastive and historical pragmatic studies in Section 4).

Contrastive studies as a subfield of linguistics thrived in the 1970s through early 199os, and established a paradigm that has paved the way for the study of contextualised language use in different periods (Jacobs and Jucker 1995: 3-4; Archer 2017:4). Initially, the rationale adopted from contrastive analysis was that comparisons of linguistic units of semantic, functional or pragmatic nature may be conducted across different dimensions: geographical, social or stylistic. Thus, extending such comparisons and contrasts to the historical dimension was viewed as a relatively straightforward conceptual leap, but diachrony can also provide a relevant dimension for comparison (for diachronic contrastive studies in English politeness, see Watts 1999 and more recently Jucker 2020; for a contrastive study on Old, Middle and Early Modern English speech acts, see Kohnen 2008; and between various periods in Chinese, see Pan and Kádár 2011). In addition, the foundational principle of variationist historical linguistic studies, uniformitarianism, gave additional support to this approach (Stein 1985: 348-349). ${ }^{4}$ Soon, however, theoretical and methodological challenges posed by this transition came to the fore (Jucker 2000 and 2004). In particular, the restrictions on historical data and methods of inquiry with the difficulty and necessity of establishing a valid tertium comparationis have been emphasised. Nevertheless, neither pragmatic form nor linguistic function may unreservedly be taken to constitute a platform of comparison for historical pragmatics (Jucker 2004: 208). A range of methodological and theoretical solutions were proposed in the next decade to overcome this challenge (see Taavitsainen and Jucker 2010 for an overview). In the attempts to solve "the bad-data problem" 5 and to provide a new take on the issue of tertium comparationis, the methods of doing historical pragmatics have diverged from contrastive analysis, and new theoretical frameworks of particularly complex interactional phenomena, such as speech acts, have been developed

4 "Only if we can safely assume that the same functions or meanings existed in society at two different points (e.g., (...) requesting information in questions) can we build hypotheses on the forces operating in linguistic change on features of differences or identity in their realisations." (Stein 1985: 348). See also Lass (1997: 24-32).

5 The term comes originally from Labov (1972), who describes Historical Linguistics as the art "of making the best use of the bad data" (1994:11). 
(see section 3). These new approaches to the study of pragmatic phenomena of the past and their developments over time have marked a transition from the initially strong reliance on the uniformitarian hypothesis to a much more restricted view of its applicability. The notion of pragmatic space, for instance, employed as point of reference for the study of speech acts not only underlines contextual aspects and the fuzziness of pragmatic phenomena both synchronically and diachronically; the axis from sincere to ironical and sarcastic language use is particularly important in literary texts with subtle shades of meaning. We have, however, textual clues to overcome the difficulty in some fairly rare cases, as authors may provide metacommentaries with explicit statements on the purpose of the speech act or specify its way of delivery. This "ethnomethodological" data opens up a new window to the past revealing how people described, classified and evaluated speech acts at their times and can be applied to supplement analysis (see below).

Given the body of work on the methodologies of historical pragmatic research, it is interesting to observe that the digital turn and the rise of linguistic interest for communication through new media have recently brought about a theoretical approach that is also relevant for the interface with contrastive study. The trans-historical approach relies on "establishing continuities in practice and enduring elements of human communication which transcend social boundaries" through a "comparative or contrastive approach (...) across multiple points in time" (Tagg and Evans 2020: 6). This perspective follows a rather strong version of the uniformitarian principle and underlines the conceptual connection between historical and contrastive studies, as in the early studies on historical pragmatics mentioned above. Although the topics undertaken within this approach focus on form (e.g. spelling practices), their affinity to historical pragmatics is clear as their aim is to develop an understanding of technology-related language change as well as to probe into the construction of identities and dynamics of social interaction by "recognising the historically and culturally situated nature" of language practices and their social meanings. Thus, the transhistorical approach, despite its comparative orientation and reliance on the common platform of comparison, i.e. the notion of language and literacy, still enables the view that such practices tend to have divergent contextual functions in different points in time.

The pioneering project in contrastive pragmatics was the Cross-cultural Speech Act Realisation Project (cCSARP) (cf. Blum-Kulka, House and Kasper 1989); the first historical SA studies came several years later. The pioneering project 
compared the realization of requests and apologies in several languages and across different cultures. The working hypothesis was that the illocutionary force of the utterance is comparable across languages, although the formal realisations may differ. This study relied on the Discourse Completion Test (DCT) method and informants were to fill in how they would perform the SA in question. The DCT method was innovative thirty years ago, and it has become a standard elicitation method in pragmatic studies. However, data elicitation has become more eclectic since, especially as the need for authenticity has become more emphasised in both spoken and written data. Here, electronic databases of naturally occurring communication have provided a new standard source of language data not limited to predefined contexts. Furthermore, a wider discourse context is a new prerequisite for analysis as the present trend regards meaning as emergent, discursively negotiated between text participants in different contexts. A more context-sensitive and representative data approach has also been advocated, and the trend in recent research seems to be from cross-cultural comparisons towards an analysis of real-life data based on the socio-cognitive and affective implications (Crashaw 2017). Another more recent insight is that different cultures have different ranges and formulations of sAs, for example, greetings follow different patterns with formulaic follow-up questions in some cultures, compliments are paid more routinely in some cultures, and so on. This area is central in cross-cultural pragmatics, and from a socio-cultural point the developments in earlier language phases provide interesting topics of research.

Diachronic speech act analysis generally focuses on comparisons of language use between the different periods of the same language. It may, however, be pertinent to consider such studies as a special case or an application of contrastive studies, though there is a fundamental difference: contrastive pragmatic analysis proper compares the manifestation of a pragmatic aspect of language use in disparate contexts, whereas diachronic analysis of a language is linear with continuity between the older and the more recent stages (see Jucker and Taavitsainen 2000: 68). If we take a broad view and understand such studies as adjacent or related to contrastive pragmatics, the scope widens considerably: diachronic developments of various SAs in different periods in the history of English have received a great deal of attention and other languages have also been dealt with (e.g. classical languages in Risselada (1993), Fedriani (2017) and further contributions to Denizot and Spevak (2017, eds.); Schrott (2000) and King (2010) have dealt with Old and colonial Spanish; Schlieben-Lange has dealt with German (1983)).

During the last decade, diachronic SA study has become a major field of corpus pragmatics (see Taavitsainen, Jucker and Tuominen 2014, Rühlemann 
and Aijmer 2015: 14). Yet it has problems: SA identification is often difficult, especially in indirect manifestations that do not give clues that include IFID s or formulaic patterns. However, the problem faced by contrastive pragmatics is also present: do the same meaning constants work across cultures and across time? Developing the theoretical basis of speech act studies has inspired researchers to new explorations. The notion of pragmatic space (mentioned above) is one of them, developed for the study of insults in different periods of English with an analytic grid for speech act manifestations through time (Jucker and Taavitsainen 2000). The point of departure was the function, with insults defined simply as disparaging utterances to the target (who recognises it as such). This function serves as tertium comparationis that remains stable and provides the basis for comparison (Jucker and Taavitsainen 2000: 68, 2008: 229). The examples given in the article are eclectic and cover the long diachrony from Old English to Present-day internet language and contain several different kinds of insults. The survey across time begins with "flyting" in sequences of ritualistic boasts and challenges from the Anglo-Saxon period. A trait with ritualistic insults like flyting can be found in different manifestations across time. The same kind of activity, called "sounding", has been verified among Afro-American adolescents (see also Arnovick 1999) and, interestingly, internet flaming is also expressed in cumulative sequences that attack the recipient's face. These three examples are clearly distinct and have a great deal in common with manifestations of aggressive linguistic behavior in other languages, and could provide interesting material for a contrastive study (see section 4). Another line that would merit contrastive study focuses on what was considered insulting in different periods, including name-calling, disparaging comments about family and national stereotypes; a survey throughout the various periods in the language history of English was conducted with the ethnographic method (see above) on the speech act verbs used in text passages with insults (Taavitsainen and Jucker 2007).

\section{4 \\ Forms of Discursive Behavior in Interaction}

Cross-cultural variation has been of interest to research into discursive behaviour beginning with Gleason (1968) focusing on discourse structures in narratives, Coulmas (1981 ed.) on conversational routines in different languages, House's work on contrastive discourse analysis (1985) and politeness markers (1989) in English and German. This approach started gaining momentum with Brown and Levinson's work (1987) based on different cultural and linguistic circles, also external to Europe. Cross-cultural and cross-linguistic contrasts 
have been the focus of the studies conducted with the discursive approach to (im)politeness the Linguistic Politeness Research Group established in 1988 (see Kádár and Bargiella-Chiappini 2011: 1). This approach relies on the assumption that in interaction all meanings are negotiable and negotiated among the parties and need to be viewed regarding the macro as well as well as micro contextual cues. This means that contrasts and affinities established on the level of language or culture are gradable rather than absolute may or may not surface in all cases. The discursive approach was extended to historical studies, in particular in research into impoliteness paradigms including their synchronic variation and diachronic developments (Culpeper and Kádár 2010 eds.; Culpeper \& Demnen 2011). Even though explicitly contrastive historical studies are not commonly found (an exception is the most recent paper by Kádár and House 2019), earlier investigations, in particular into Chinese (Kádár 2012, 2007) and East Asian politeness more broadly (Kádár and Mills eds. 2011), tend to use studies into European languages as an important point of reference. For instance, regarding Bax's findings (2010) on mediaeval rituals, Kádár (2012: 101) notices a difference in the norms of indirectness, with the Chinese data being more constrained. This constitutes a striking difference to the contemporary patterns, with indirectness being conventionally associated with East Asian communication. At the same time, Kádár underlines that no clear-cut dichotomy between Eastern and Western rhetorical styles exists. Instead, he proposes the view of "culture-specific preferences for certain politeness rhetorical patterns” (Kádár 2012: 98, italics original).

Rituals constitute another important dimension of discursive behavior and have been subject to investigation from a historical perspective. For instance, the Special Issue of Journal of Historical Pragmatics (2003, Bax ed.) and the most recent issue of Journal of Pragmatics (2019, Aijmer et al. 2019 eds.) combine the historical and contrastive dimensions of the notion. Authentic oral conventions, such as flyting and polite ostentation are the focus of attention providing a comparative overview of the records of the phenomenon in different languages, cultures and genres (e.g. Old Icelandic sagas and Dutch epistolary communication in the sixteenth century; Bax 2003 ed.). The most recent volume introduces a broader notion of "ritual frame indicating expressions" (RFIEs) within a "ritual frame" defined as a cluster of standard situations which occur cross-culturally. The authors explicitly indicate the interface (RFIES) with historical pragmatics: "It is possible to combine such research with additional methodologies, such as historical pragmatic research on the development of RFIEs, the sociocultural investigation of their use, and so on, which would provide us with a clearer understanding of how the use of an RFIE has developed over time." (Kádár and House 2019: 11). 
Ritual frames as a dimension of discursive behaviour provide a fruitful ground for investigating the linguistic expression of stance. ${ }^{6}$ Both epistemic as well as emotional attitudes to the propositional content and alignment in interaction have been studied extensively in historical pragmatics, not only in English (Biber 2004; Valle 2004), but also in other languages (e.g. Gunnarsson 2001 on Swedish; Tiisala 2004 on Hanseatic letters). More broadly, stance expressions together with features such as first and second person pronouns, modal auxiliaries and private verbs, contribute to the creation of "involvement" (Biber and Finnegan 1997; Taavitsainen 1997; Palander-Collin 20o9; Włodarczyk 2013; cf. Baumgarten et al. eds. 2012 which contrasts a range of languages). Stance expressions lay the foundations for the interpersonal dimension of interaction and provide a leeway into how its aspects are negotiated among the participants. Corpus-based studies in historical pragmatics have provided important insights into the medium-related patterns of stance expression, discourse and genre dimensions, as well as sub-genre effects on attitudinal and alignment markers in particular in British and American English.

The infrequent contrastive historical pragmatic studies rely on the data provided by communities of practice which were networked internationally in the past. This involves the epistolary and academic communities especially in the Early Modern and Late Modern Europe. For example, Tiisala's investigation into Latin, German and Swedish letters of the Hansa incorporates the multilingual background of the contemporary trade relations (1350-1530). The results of the study show a universal dimension of epistolary politeness, reverential stance reflected in the conventionalised address formulae and respectful adjectives in the salutations. The paper also underlines macro-contextual, i.e. social and political features of code-switching. In the area of the language(s) of science, Salager-Meyer and Zambrano (2001) investigate English and French academic conflicts over the period of 185 years of medical discourse (1810-1995). The study assumes that professional and academic conflict is an "interpersonal pragmatic feature" (2001: 142) and shows its dependence on culturally-specific understandings of the concept of science and debate. The results indicate differences in terms of directness in the early conflicts with the English community using more mitigating devices than the French (2001: 165-166). The distinctions seem to be valid until today with French scientists taking a more authoritarian position that those writing in English.

6 Biber also provides terms such as evaluation, affect, evidentiality, hedging (2004: 107, 108). 
Although truly contrastive papers are an exception (but see Salager-Meyer and Zembrano 2001 and Tiisala 2004), historical pragmatic research conducted into languages other than English may in the future be used as a stepping stone to contrastive historical studies into stance, discourse particles, speech acts and discursive behaviour more generally (e.g. Schlieben-Lange 1983; Schrott 2000; King 2010; Held 2010). Having provided an overview of the units of analysis we would like to argue that these provide a holistic replicable model for historical contrastive studies (Sections $3^{-5}$ above). We implement the model in the case-study we present below (Section 6) focusing in particular on the pragmatics of terms of address, interjections and speech acts. In addition, the study incorporates translation studies into the discussion demonstrating the potential for modification and extension of the analytical grid proposed above.

Contrastive Pragmatics in a Diachronic Perspective: A Sample Analysis ${ }^{7}$

Our goal in this section is to reveal some pragmatic language- and culturespecific features that illuminate diachronic contrastive pragmatics. The extract that we chose for closer scrutiny comes from William Shakespeare's Othello (4.2.22-91), one of the canonical tragedies in Western culture. ${ }^{8}$

The tragedy was written most likely between $1601-1603$ as an adaptation from a French translation, of an Italian tale "Un Capitano Moro" ("A Moorish Captain") from Giovanni Battista Giraldi's (1504-1573, nickname Cinthio) Gli Hecatommithi (1565), a collection modelled on Boccaccio's Decameron. A story of a love affair between a successful Venetian general, a newcomer and stranger, described as a "Moor", and beautiful Desdemona, daughter of a Venetian senator, develops into a tragedy of revenge, manipulation, jealousy and rejection of otherness. The plot is propelled by Iago, Othello's servant and long-standing battle comrade, husband to Desdemona's maidservant, Emilia.

7 We are grateful to Dr. Nely Keinänen (University of Helsinki) for her comments on this section.

8 Its first performance was in 1604, but Shakespeare's works have only come down to us in printed editions: the so-called First Folio (1623) and Second Quarto (1622) are thus closest to the authorial originals. The editions differ considerably (B. Busse and U. Busse 2010: 249; cf. e.g. empirical studies by Jenkins 1955; Honigmann 1996). The majority of the translations we have looked at seem to have consulted both versions, as well as modern ones. Our quotations come from the Riverside edition, which relies on the Second Folio (1623) in terms of contents, with modernisation of spelling, capitalisation and punctuation. 
Iago is the villain, disillusioned with his master, deeply humiliated by Othello's choosing to promote a young soldier, Cassio, for the position of his lieutenant. The scene selected for analysis $(4,2)$, sometimes referred to as the "bordello scene"9 (Van Oort 2016: 130), starts at the point at which Iago's intrigue has led Othello to look for material evidence of his wife's infidelity after he has taken the decision to murder her for adultery subtly staged by Iago.

The scene contains extreme emotions revealed in relational work between the protagonists with a variety of linguistic features, sentence types and speech acts. Terms of address occur ranging from endearment (albeit sarcastic) to abuse. Meanings vary according to several sociolinguistic (social status, relationship) and pragmatic (situational and contextual) parameters in culture-specific uses with changing conventions. Momentary shifts with interpersonal negotiation can also be verified in the tu-vous $(\mathrm{T} / \mathrm{V})$ vacillation. ${ }^{10}$ Expressive and directive speech acts are of particular interest to us, as they contain pragmatic features, cumulative sequences of personal insults and religious vocabulary.

We shall focus on four European languages: German as a close kin to English and Swedish from the Scandinavian branch; Polish as an Indo-European language of the Slavonic group; and Finnish as a non-Indo-European language of the Finno-Ugric family, but pragmatically close to Swedish for historical reasons. We analysed two or more published versions in each language: the first translations date from the "vernacularisation" boom of the nineteenth century that was one of the manifestations of Romanticism in literature and the modern versions come from recent decades.

The early German translation, known also as the canonical Schlegel-Tieck edition ${ }^{11}$ comes from $183^{2}$ (G1832). ${ }^{12}$ The more recent version by Frank Günther dates from 1999 (G1999). The first Polish translation was prepared in 1834 by Ignacy Hołowiński (P1834), ${ }^{13}$ another in 188 o by Szczęsny Kluczycki (P188o); the third in 1895 by Leon Ulrich (P1895); the fourth in 1925 by Józef Paszkowski

9 This is due to the fact that Othello frames the exchange (more aptly, interrogation of his wife) into a visit to a brothel, treating Emilia as the madam and paying her for the services of his wife.

10 The conventional way of referring to the pronoun system with the abbreviation is originally from Brown and Gilman (1960: 254). Calvo's pioneering article (1992) on momentary shifts received continuation in studies by U. Busse, Mazzon and Stein (all in 2003).

11 This version developed between 1789-1832 on the translations of August Wilhelm Schlegel started the late 18th century, with modifications by Ludwig Tieck in the 1820 s and Wolf Heinrich von Baudissin und Dorothea Tieck in the 183 os.

12 We use the letters G, P, S, and F to indicate the languages and the years of publication.

13 The manuscript version of this translation allows some observations on corrections and amendments of pragmatically sensitive items. 
(P1925); the fifth in 1956 by Krystyna Berwińska (P1956); and the sixth in 2002 by Stanisław Barańczak (P2002). The first Swedish translation, by Carl August Hagberg, dates from 1850 (S1850). ${ }^{14}$ The modern Swedish version by Mats and Lars Huldén is from 2003 (S1987). Shakespeare's works were introduced to Finnish in the 1880s in translations by Paavo Cajander; Othello came out in 1884 (F1884) and a slightly modernised version by Yrjö Jylhä in 1915. For modern translations we selected Matti Rossi (F2OO3).

After a short discussion on the original English text, we survey aspects of pragmatically sensitive translation variants (see House 2015). Efforts to mirror stylistic effects of the original language were made in various ways, and our analysis gives evidence of some culture-specific features as well as linguistic creativity, but it also revealed fundamental difficulties in this kind of analysis. We proceed as the dialogue unfolds, with the different pragmatic functions intertwining and building up an intensive negotiation that leads to Othello's outburst in verbal violence. At the end, we shall discuss the cultural impact of Shakespeare's translations on various languages.

\subsection{Terms of Address}

Personal address uses both nominal forms and pronouns. Desdemona addresses her husband respectfully with "my (noble) lord", e.g. in the scene where she appears with a slight delay when sent for by Othello. Des. "My Lord, what is your will?" (line 24); a nominal address with lord always implies a social hierarchy and it also has religious connotations. ${ }^{15}$ As a default, Desdemona uses you when addressing her husband, but a shift from $V$ to the T-form occurs in her appeal to her husband, intensifying her plea with intimacy. As a rule she receives the T-form in return, in accordance to the politeness rules of their social class. During Shakespeare's time, the T/V distinction was in a state of flux, and could also be used to express momentary shifts in attitude as is the case in one of Othello's speech turns in the passage. All languages under scrutiny had pragmatic as well as grammatically encoded forms that clearly distinguish between $\mathrm{T} / \mathrm{V}$ forms.

The early German translation of the nominal address has "Mein Gatte" and "Mein Gemahl" ('my husband'; G1832), while the modern one has pronominal address in the T form (G1999). Similarly, the Polish translators chose the term referring to the marital hierarchy modified by a possessive pronoun ("mój

\footnotetext{
14 The numerous Shakespeare translations by Per Hällström do not include Othello.

15 As e.g. in the canonical prayer "Our Lord ...". This noun has also acquired several metaphorical uses, and even subversive meanings, but they are not relevant here (see Taavitsainen 2006).
} 
mężu" P1895 and "mój małżonek" P1925). ${ }^{16}$ It is quite striking that at this particular point none of these translations involves an equivalent to "lord" in the exchange between Othello and Desdemona, though available in both Polish and German. The use of the nominal address does not occur in the remaining translations. Instead, the solidarity-based pronominal address is used in Polish, but it is rarely explicit, as the language allows subject omission as a syntactically normal feature that may be viewed as neutral. However, it reduces the visibility of the addressee and does not underline respectfulness or acknowledge the patriarchal nature of the marriage. Likewise, the Swedish translation from 1850 has "min gemål" which equals 'spouse' and does not imply a hierarchical relation. S1987 has "min käre man" with a totally different tone of affection on equal standing. In contrast to the others, Finnish has retained the same connotations as the original: F1884 has a somewhat blunt "Täss' olen, herrani" 'I'm here, my lord', F1915 has "mun herrani" likewise with the possessive pronoun 'my' (spelled out), and F2003 makes the hierarchy even more explicit with "armollinen herrani" 'my merciful lord'.

Pronominal forms of address have undergone a radical change in both Swedish and Finnish as the current data demonstrates. Not only is there vacillation between the $\mathrm{T} / \mathrm{V}$ forms, but the politeness convention with deference expressed by indirectness using the third person singular instead of the second (either $\mathrm{T}$ or $\mathrm{V}$ ) is also attested in the translation variants from different times. ${ }^{17}$ In Swedish, the following turns show vacillation: S1850 "Vad önskar ni? (pl V) ... Vilket rysligt infall!" (impersonal formulation "What a terrible accident') ... "Jag hoppas min gemål mig anser kysk" (3rd person polite address with 'my husband'). S1987 "Vad önskar du? (T) ... Vad är det här??" (impersonal formulation) ... "Jag hoppas att du litar på ..." (T-form 'I hope you trust ...').

Likewise in Finnish, but with somewhat different choices: F1884 'Mik' on sun tahtos? ... Mit' aiot?" ('What's your intention?' T) ... "Toivon, et uskoo jalo mieheni mun puhtaaks ..." (3rd person address with 'my noble husband'); F1915 "Mitä suvaitsee mun herrani?" (3rd person address with 'my master') ... “Ja mitä hän tahtoo?" (3rd person address 'What does he want?'), "Sun toivon uskovan, ett' olen puhdas" (T); F 2003 "Mikä on tahtonne, armollinen herra?" ('What is your will, merciful lord' (V)) ... "Mitä haluatte?" ('What do you want?'

16 It is not possible to separate nominal and pronominal address entirely in the case of Polish. The formal nominal forms have undergone pronominalization; the boundary is blurred here.

17 The polite address form in Finnish show the influence of Swedish, as the upper classes were Swedish speaking in the nineteenth century. 
V) ... "Toivon, ett' armollisen herran mielestä olen ..." (3rd person reference 'that merciful lord will consider ...').

Othello's speech contains an expressive shift in pronoun use from intimate to distant, reflecting the growing suspicion "Why, what art thou?" (line 33) ... "Are not you a strumpet? (line 82) ... What, not a whore?" (line 86). In the Swedish translations the T-forms prevail: S1850 "Vad är du för en? ('What are you?' (T)) ... Du ingen kona? ... Du ingen sköka?”; S1987 “Säg, vem är du? ('Who' (T)) ... Är inte du en hora? (T) ... Så, ingen hora” (elliptic)?

In earlier Finnish versions T-forms prevail F1884 "Mik' olet sinä?" ('What' (T)) ... “Sinä etkö portto? (T) ... Sin' etkö huora?” (T) F1915 "Ken olet sinä? ('Who' (T)) ... Sinäkö et ois portto? ... (T). Vai et siis huora?” (T). Only the modern translation F2003 catches the pronoun switch to $\mathrm{V}$ emphasising the growing distance: "Mikä sinä olet?” ('What' (T)) ... "Ettekö siis ole portto? ... (V), Mitä, ettekö te ole huora?" (V). ${ }^{18}$

Emilia (the servant) addresses both Othello and Desdemona in socially appropriate and neutral terms. ${ }^{19}$ In German, the appropriate neutral forms involve nominal address with that corresponds to "lord" and the V pronoun "Ihr" and "gnäd'ge(r)" ('My Lord/Lady; Sir/Madam') as in "gnäd'ger Herr" addressed to Othello or "Wie geht's Euch, teure Frau? Wie geht's Euch, Gnäd'ge?" to Desdemona (G1832). The form "gnäd'ge(r)" is a contemporary conventionalised term of respectful address to social superiors or equals, as the omission of the noun in "Gnäd'ge" shows. The twentieth century translation uses "Mein Herr" ('My Lord'), "gnädige Frau", "meine süsse Herrin" and "Ihr" (G1999). The latter is a literal rendering of the original "you" found in Shakespeare, rather than the expected contemporary "Sie", which is the third person plural form.

In the Polish translations, "mój Panie" ('my Lord' P1834), "najłaskawszy Panie" ('most merciful Lord', P1834), "panie" ('Sir') $(1895,1925,1956,2001)$ are used by Emilia to address Othello. At the same time, the agreement with the verb is with the second rather than the third person singular, a neutral syntactic choice possible for the conventionalised V form in Polish ("Pan, Pani"/'Sir, Madam') (e.g. "Jeśli inaczej myślisz, Panie”, 'if you are thinking differently, Sir' P20o1). In contemporary Polish, "Pan/Pani" (and the plural "Państwo") are technically nominal, but Braun notices a tendency for pronominalisation (1988: 60 ). This type of agreement signals it, as well as a reduced distance with a lower

18 The fact that Cajander was striving to use iambic pentameter and hence needs a shorter form may have contributed to the choice of the T-form; Rossi was not counting the syllables.

19 Yet her close and fond relationship with Desdemona surfaces sometimes in modifiers and terms of endearment. 
degree of formality (cf. Braun who considers these forms non-standard, 1988: 60 ). Both the German and Polish translators tend to preserve the and person forms that blur the $\mathrm{T} / \mathrm{V}$ distinction rather than emphasising respectful address with the $\mathrm{T} / \mathrm{V}$ distinctions available in the target languages.

In Swedish and Finnish, Emily addresses both Othello and Desdemona respectfully: S1850 "nådig herre", "Ers nåd", S185o "nådig fru". In contrast, Othello's speech changes in the course of events so that the neutrally polite "min fru" at the beginning of the scene becomes impolite abuse. Emily's application of address terms is in accordance with to the rules of social etiquette S1987 "Jag undrar vad herrn menade med det? Hur är det med er, frun? Hur mår ni frun?" Generally, the translations follow the original fairly closely. An exception is found in Othello's request to Emilia in S1987 that renders it creatively with a modern-sounding phrase that in speech act terms could count as flattery with conventional politeness in the third person combined with a respectful nominal address "En yrkeskunnig kvinna av er sort, min fru, förstår att ..." 'a competent woman like you, my lady, understands that ...'20 However, the utterance is highly sarcastic turning what could be taken as a complement to its opposite, an insult.

The following line poses challenges with its metaphorical address that has been rendered in different ways in different languages. Othello uses a common contemporary term of endearment, but its subtle shade of meaning needs to be considered in its larger discursive context; here the use is sarcastic:

Oth. Pray, ${ }^{21}$ chuck, come hither.

The term is related etymologically and semantically to chick, chicken (OED). In German, this is rendered as "Täubchen" ('dove' in diminutive). In Polish the same lexeme is rendered ("gołąbko", 'pigeon', diminutive; P1956), or as similar terms of endearment derived from the animal kingdom "kurczątko" ('chick', in diminutive), "rybko" ('fish', also diminutivised), "ptaszku" ('birdie'; P2oo1) and "buziaczku" ('sweet face, kiss,' in diminutive). The last translation seems striking as it does not denote an animal, but a human body part or a fond gesture. Swedish has a very different rendering in S1850: "Kom hit, min docka!" 'my doll' which has entirely different connotations of the lack of human feelings.

In Finnish, a radical difference is found between the old and the new translations: “Käy tänne, hemppu!" (F1884) 'beloved one' > 'slut' perhaps the term

\footnotetext{
$20 \quad$ S185o has the V form "Ni, / Som har en syssla ..." 'you who have ...' ; F1884 has a free rendering with reference to heaven and an exclamation plea to God's mercy and St Peter.

21 In the Second Folio: "pray you".
} 
had already gained pejorative meanings (Nykysuomen sanakirja) and is used paving the way to the insults scene. F1915 has "kyyhkyläiseni" 'pigeon' (in diminutive) conveying the original tone, but the modern version (F2003) deviates from the line with "Tulehan tänne, lintuseni!" with a diminutive form of 'bird' and the possessive suffix ni 'my'; Desdemona is Othello's bird. The noun is frequently used in folklore for genuine affection, but the scope for sarcasm is high in this context. However, the verbal form with the hedging suffix (tule imperative 'come' + han) leaves room for voluntary action and contributes to a more gentle tone.

\subsection{Pragmatic Noise, ${ }^{22}$ Interjections, Religious Terms}

Othello dismisses the maid, Emilia, telling her to stay on guard and "Cough, or cry hem" (line 28), if someone comes. This is rendered literally "Hust' oder rufe 'hem!'” (G1832), as both languages have an onomatopoetic word for the sound of clearing one's throat; likewise in Swedish, "Och hosta, ropa hm!" (S1850). In Polish, the pragmatic noise "hmmm" sounds similar, but expresses a different meaning (e.g. pondering upon something or confirmation) and is omitted; the imperatives denoting coughing and clearing one's throat are given as "Kaszlej $i$ chrząkaj” (P1925), "Kaszlnij lub chrząknij” (P20o1). A verb of clearing the throat enforced by the imperative form (in reverse order) in F1884 "Rykikää, yskikää", and F2003 adds the pragmatic noise "huudatte tai yskäisette ' $\mathrm{hm}$ "' as an attention getter, though it can also mark hesitation or pondering, as in Polish. Thus, pragmatic noise has been rendered in fairly straight-forward ways.

A key passage follows. Othello has found the handkerchief and drawn hasty conclusions of Desdemona's infidelity. She poses an innocent question, but receives a rude answer with a vocative first-name address "Ah, Desdemon!" and a command with the adverb away repeated three times:

\section{Oth. Ah, Desdemon! Away, away, away!}

Act IV, scene ii, line 40

This line begins with nominal address and has received faithful word-for-word counterpart in most translations: "O Desdemona! Hinweg, hinweg, hinweg!" (G1832); "O, Desdemono! Precz, precz, precz!" (P1895); "O, Desdemona! - Bort, bort, bort!" (S1850); Oi Desdemona, - poistu, poistu, poistu! (F1884 'go away', imperative). Both the initial interjection (albeit in a changed form) and the repetition of the adverb have been preserved showing that the English marker

22 This term was launched by Culpeper and Kytö (2010) and includes onomatopoetic sounds, hesitations and disfluencies. 
accompanying a sigh $\left(a h, o h, o,{ }^{23}\right.$ etc. $)$ is directly translatable into these languages. A subtle difference occurs in Polish due to the inflectional nature of the language, the first name is rendered in the vocative case ending in -o which underlines the direct nature of this address form. However, the second part of the same performative speech act is expressed differently: "O Desdemono! Precz! precz że ode mnie! precz!" (P1834). Here, the repetition is reduced to two items and the clitic - $\dot{z} e$ intensifying verbal imperatives is attached to the adverb. The enhanced form, which in fact performs an imperative function, is followed by a prepositional phrase with the first person dative pronoun meaning "from me", thus personalising Othello's order. This version appears more expressive as it utilizes a grammaticalised intensifying clitic and is more focused on the agency on Othello than P1895, which paralleled the original. P2oo1 replaces the adverb "precz" 24 with a verbal imperative: odejdź 'go away', most likely for sound harmony effects (repetition of the consonant $/ \mathrm{d} /$, as in the vocative 'Desdemona').

The modern Swedish "Å, Desdemona, gå ifrån mig, gå!" (S 2003) has an imperative emphasised by repetition 'go away from me, go'. In F1884, the interjection "Oi" is in accordance with the old customary way of translating Latin vocatives, but omitted as archaic in $\mathrm{F}_{2} \mathrm{OO} 3$; however, the plain name casts a rude tone to the command "Desdemona, mene pois, pois, pois."

Desdemona's ignorance of the deception is shown in her reaction with the prototypical interjection of distress and a reference to the unhappy day with the adjective heavy; a collocation that became a common stock phrase in English.

\section{Des. Alas, the heavy day! Why do you weep? ${ }^{25}$}

The reply opens with the interjection Alas. ${ }^{26}$ It does not have a lexical counterpart in German or Polish and is rendered as "o!" (G1832; P1895 and P1925) and "Ach" (P1834). In P1895, this interjection is preceded by "Niestety!" (literally: 'unfortunately'); in effect, this version covers two expressive words as a solution to a lexical gap. The expression of sorrow ("heavy day") is translated

\footnotetext{
$23 O$ followed by a term of address may also be viewed as a morphological marker of the vocative, rather than an interjection alone (B. Busse and U. Busse 2010: 259).

24 Precz in Polish is actually a particle-interjection with reduced adverbial functions and very restricted semantics of fury or aggression. It may be stand-alone or governed by a narrow group of verbs denoting movement, i.e. unlike the English "away" which combines freely with verbs of a broad semantic scope.

25 This line is quoted in OED as an example of s.v. alas the day and variants.

26 See Taavitsainen 1995 for a historical overview of English interjections.
} 
literally in all but one version, where the exclamatory "O, mój Boże!" (P1925, 'my God!', vocative; also in P1956) invokes the name of God. Similarly, for Alas (Desdemona's line: "Alas, what ignorant sin have I committed?"), "Mój Boże" (P2001) is given. The exclamation may simply be seen as a common expression in spoken Polish especially in the late twentieth century, with very bleached religious connotations. Both in Swedish and in Finnish customary interjections of stereotypical lamentation are used: "Ack, olyckfulla dag" (S185o; cf. P1834) and "Voi, päivää onnetonta!" (F1884).

\section{Had it pleas'd heaven}

To try me with affliction, had they rain'd

All kinds of sores and shames on my bare head,

Steep'd me in poverty to the very lips, ...

lines $48-50$

Othello's emotionally heightened soliloquy begins with reference to heaven and religious vocabulary is dispersed throughout the scene, reflecting the overarching cultural heritage of Christianity. A cumulative list of misfortunes that can be tolerated (sores, shames) follows, coupled with miserable conditions (poverty, captivity) that add to the distress. The passage also contains expressive verbs in powerful images connected with body parts: "rained [...] on my bare head"; "Steeped me [...] to the very lips" (see Murphy 2015).

I should have found in some place of my soul

A drop of patience; but, alas, to make me

The fixed figure for the time of scorn

To point his slow [unmoving] finger at!

Yet could I bear that too, well, very well;

But there where I have garner'd up my heart;

Where either I must live or bear no life ...

Act IV, scene ii, lines $5^{2-} 5^{8}$

The collocation but alas has a discourse marker function. The culmination follows with a contrast to the unbearable, immediately cancelled by yet, implying that such a fate could also be tolerated. Only the ultimate remains: death with the loss of love. All translations follow the original fairly closely: the sentence types have been retained in fairly exact renderings of the original with vivid imagery and expressive verbs. Interestingly, an additional line occurs in S185o as well as F1884 (perhaps after the Swedish model) with the interjection $O, o$ ! repeated twice to make the emotional impact even stronger. The Variorum edition of Othello, however, points out that a similar line with $O h$, oh or $O ! O !$ is 
found in some early versions of the play text. Thus, instead of being an addition, it reveals that the exemplar was another text; F2003 adds a note valittaa 'lamenting' as a stage direction.

Othello reflects upon enduring the calamities of fate by finding patience "in some place of my soul". All translations into Polish use the lexical counterpart soul "dusza". In G1832 the word "Herzenswinkel" [a corner of the heart] is used instead. It is impossible to include a systematic overview of all translations in the analysis, but P188o uses "w zakątku serca mego" as a strikingly close rendition of this German compound (with the stem of "zakątek", "kąt" meaning "Winkel" (i.e. corner)). The influence or inspiration drawn from G1832 translation cannot be excluded here. The Swedish and the Finnish versions refer to the soul.

Religious terminology makes a textual chain with the contrast of heaven and hell at several places in this scene. Othello describes Desdemona "... being like one of heaven, the devils themselves/Should fear to seize thee ..." (lines 35-36). The same dichotomy is present in Des. "Heaven doth truly know it." Oth. "Heaven truly knows that thou art false as hell." Desdemona's defence against accusations appeals to piety, "No, as I am a Christian" (line 83).

In the German and Polish translations, the word heaven is translated with the expected "Himmel" and "niebo" in all but two versions analysed here. P1834 uses "Bóg" [God] in the above accusation. P188o also uses God instead of heaven not only in the attack on Desdemona, but also in Othello's monologue, G1832 use "Gott" in the Othello monologue, but "Himmel" in the accusation line. Although it would be hazardous to jump to conclusions of religious or philosophical nature on the basis of these examples; clearly, in the original version, the agency of heaven seems to be sufficient to express the ultimate judgment on human condition or fate. Both Polish and German translations tend to reach for a personified variant, i.e. God. The Swedish and Finnish versions have the original (with some variation) "helvet" S 1850, "helvete" S1987, F1884 "helvetin" (genitive), "horna" F1915; the personified version "piru" 'devil' occurs once in F2003.

\subsection{Speech Acts: Othello's Outburst in Insults Targeted at Desdemona ${ }^{27}$}

Desdemona's meek question "I hope my noble ${ }^{28}$ lord esteems me honest" (line 64) triggers Othello's anger. In return, she receives offensive accusations

\footnotetext{
27 Disparaging talk is also addressed to Emily, e.g. Iago calls her "a fool" and Othello even worse "You, mistress, / That have the office opposite to Saint Peter, And keep the gate of hell" (line 91; see above).

The word "noble" does not occur in the Second Folio.
} 
with vivid imagery and several sentence types: exclamations, questions and wishes.

Oth. O, ay: as summer flies are in the shambles, That quicken even with blowing. $\mathrm{O}$ thou weed, Who art so lovely fair and smell'st so sweet That the senses aches ${ }^{29}$ at thee, would thou hadst ne'er been born!

Des. Alas, what ignorant sin have I committed?

Oth. Was this fair paper, this most goodly book, Made to write "whore" upon? What committed! Committed! O thou public commoner!

... What committed!

\section{Impudent strumpet! ${ }^{30}$}

Des. By heaven, you do me wrong.

Oth. Are not you a strumpet?

... Oth. What, not a whore? ...

lines $66-82$

\section{Oth.... I took you for that cunning whore of Venice ... lines 88-9o}

Othello uses several different terms of abuse: "O thou weed", "whore", "Oh thou publick commoner", and poses interpersonal questions in a sequence that culminates in a sarcastic statement: "I took you for that cunning Whore of Venice that married Othello, You Mistris."31 The shift to the third person when speaking about himself, has a peculiar distancing effect reflecting his confused state of mind.

The early German translation uses direct counterparts in the first three cases: "O du Unkraut", "Metze", "O du ganz freche Buhlerin!" (G1832), then, terms: "Metze", "Hure", "Dirne" are used respectively. Despite the availability of the etymologically related term (i.e. "Hure"), it is noticeable that "Metze" and "Dirne" (G1832), which denote the profession more specifically, rather than a general pattern of behavior or adultery, replace two instances of "whore". If we assume that meaning b. rather than meaning a. in $O E D^{32}$ is expressed, the German translation appears to tone down the personally abusive terms.

\footnotetext{
29 Second Folio: "askes".

30 The phrase does not occur in the Second Folio.

31 "You Mistris" is omitted from the German and Polish translations, difference most likely to the selected original version (First Quarto or Second Folio).

32 OED (a: 'A woman who prostitutes herself for hire; a prostitute, harlot'; b: 'More generally: An unchaste or lewd woman; a fornicatress or adulteress').
} 
Sensitivity of terms of abuse, in particular items related to taboo activities, such as paid sexual services and extramarital intercourse, surfaces clearly in the variation illustrated by Polish translations. The earliest of the analysed translations ( $\mathrm{P} 1834)$ uses three terms corresponding to prostitute and adulteress: "kurwa" (repeated three times as equivalent of "whore"), "nierządnica publiczna" (public commoner) and "tłuka"33 (for 'Strumpet'), the closest and most direct counterparts to the original. It is noteworthy, however, that in the manuscript of this Polish translation, all three cases of "kurwa" are underlined and followed by a question mark, indicating the translator's hesitation. Euphemistic tendencies may be noticed in later translations: P1895 uses only two terms ("nierządnica" 'harlot' and "wszetecznica" 'fornicator', 'harlot'), variants occurring in biblical translations, thus of much less colloquial undertone than "kurwa". ${ }^{34}$ In one line (original "What, not a Whore?"), the taboo term is eschewed altogether (also in P1925 and P1956, e.g. Nie jesteś...?). The former chooses "nierządnica" and "wszetecznica" and adds a translation of 'public commoner' as "gminna sprośnica", a colloquial term encoding a person willingly engaging in sexual activity, but much less offensive. The euphemistic nature of this translation also features in the counterpart of the first "whore" (original: "this most godly booke made to write whore upon") as "aby jej czyste karty bezwstyd kalał" ('for its pure pages to be stained by promiscuity/sinfulness'). Here, the epithet is avoided and the word "bezwstyd" (literally 'shamelessness') is used as a rather bleak counterpart of the original. The twentieth century translations P1956 and P20o1 show opposite tendencies. The former follows the euphemistic trend: "kurwa" is used once only, while a stylised archaic, potentially semantically neutral term "dziewka" (derived from the diminutive of 'girl') is used three times. The strongest modern expression "bezczelna szmata" ('shameless slut', literally: 'cleaning cloth') occurs once as the most forceful item indicating the subordinate position of a woman by alluding to her role in the household. P20o1 chooses only two very direct colloquial and blunt terms, both clearly readable to the modern reader: "kurwa" and "dziwka" (pejoration of "dziewka" 'girl'), each employed three times.

Terms of abuse in S1850 include "sköka" (several times), "hona" and "hora" but a more poetic rendering is also found in "O, du gemena gatunymf!" 'oh, you common street nymph' The insults are spiced with mild swearing "Nej, så sant Gud hjälpe!" 'No, so true God help', and a pious wish "Gud förlåte oss!" 'God forgive us', followed by a fake apology “ursäkta mig” 'forgive me' to Desdemona. and vagabond see M. Arcta Stownik Ilustrowany Jezzyka Polskiego (1916: 70).

34 In contemporary usage, both terms have masculine counterparts, although used less frequently. 
The translations follow the original, but in $\mathrm{S} 1987$ a more modern swearing pattern is used ("Du ogräs" S1850 > "Ditt ogräs" 'you weed') as well as a less poetic variant "en kvinnsperson in allmänt bruk" 'a woman in public use'. The chain of abusive terms in F1884 repeats the biblical "portto" several times, "huora," and a descriptive coinage "julki-luuska" 'public commoner' is also present. Likewise, F1915 repeats "portto" and "huora", and the term "katulutka" 'street whore' is modelled after S1850 (see above). In F2003 the repertoire is "portto", "huora" and "jukihuora", after the 1884 text.

\section{7}

\section{Discussion}

The translation variants we have discussed were all pragmatically sensitive. In most cases, evidence has shown rich variation, which posed a challenge in terms of establishing which features may have been culture-specific and which should rather be seen as creative stylistic devices. Clearly, this task would have required much broader synchronic analyses of each variant in existing databases in order to confirm statistical tendencies and it may be pursued in further research. In many cases, the pragmatic functions that have been observed were very complex with social differentiation, power relations intertwining as well as being marked by affect and emotions. Still, some patterns have been revealed.

As the languages we analysed had a pragmatically and grammatically distinction between $\mathrm{T}$ and $\mathrm{V}$ forms, we were able to observe that unconventional items of address entail as marked usage, e.g. to express sarcasm. It has also become clear that if the systems of address were flexible or diachronically unstable, translations exploited an array of options to achieve pragmatic and stylistic effects (e.g. distancing by T forms vs. intimacy by means of $\mathrm{V}$ forms).

Interjections, pragmatic noise and religious vocabulary could be indicated as highly language specific, with many lexical gaps between languages and with differences concerning conceptualisation of Christian notions of God, soul, heaven and hell. Interestingly, in a modern Polish translation, "my God", an exclamation with both negative and positive connotations, but with the bleaching of religious connotations over time, was used to replace the English "Alas". An interesting tendency in the translations of interjections with the function of discourse markers, were fairly close to the original, reflecting and preserving the marking of discourse organisation.

The analysis of terms of abuse, taboo words and euphemisms is clearly intertwined with the expression of speech acts. Here, the spectrum of lexical and 
stylistic creativity has been very broad, ranging from euphemisms and poetic variants to extremely blunt and abusive terms and pejoration indicating the moral and social lowliness of the target of insults. Creative sarcastic variants tend to occur in connection to fake speech acts, e.g. insincere apologies.

Our paper moves at the interface of several related fields and our analysis provides a multilayered analytical grid according to which we conducted our contrastive study of German, Polish, Swedish and Finnish translations of Shakepeare's Othello at various points of time. The micro level deals with individual linguistic features used in various speech act utterances, and the macro level pertains to the situational contexts of individual turns of dialogue as well as the larger context of these dialogues.

\section{Conclusions}

At the beginning of the nineteenth century the literary registers of the languages under scrutiny were at very different stages: German had a long history; Polish literary language was established in the Renaissance; Swedish had a well-established repertoire; but Finnish lagged behind with mainly religious literature, fighting for its position and aspiring to rise to the level of Swedish as the language of culture in the country. Thus, the impact of Shakespearean translations was significant in broadening the scope and setting a model for skillful and vivid language use in new genres and registers of language use (see Keinänen 2020).

The scene selected for scrutiny in our empirical analysis displays the use of several pragmatic variants in negotiating interpersonal relations undergoing a shift and contribute to the emotional impact of this passage. As noted earlier, the G, P, S, and F translations are mostly faithful to the original, but some deviations and differences between the versions can be verified. Address terms are particularly sensitive in conveying attitudes and changing moods; they are capable of expressing even subtle momentary relational shifts. Culture-specific differences between the four-language translations come out perhaps best in their ways of depicting the growing distance between the spouses. On the one hand, the politeness conventions of early modern class society and marital hierarchy find expression in respectful speech, but the terms of male dominion are tuned down by means of more egalitarian terms in most translations; only F2003 follows the original closely. On the other hand, Othello's increasing rage is expressed with terms of sarcastic endearment and at the end of the scene his emotions burst out in disparaging language use that pertains to verbal aggression and the pragmatic space of insults. All versions display this wide scale, but 
only one, F2003, catches the fine-tuned pronominal shift in Othello's speech to Desdemona.

Expressive linguistic features like interjections contribute to the intense feelings of agony in emotional outbursts, culminating in alas; their secondary, discourse organising function is, however, also present. A culturally interesting difference pertains to the various locations attributed to emotions: $G$ and P mention the heart "Herzenswinkel" whereas $\mathrm{S}$ and F refer to the "soul". ${ }^{35}$ The passage is coloured by Christian vocabulary and the utmost dichotomy of Heaven and angels against Hell and the devil is repeated with variants echoing the confrontations of worldly power against spiritual strength in saints' lives. The onset of the Moor's increasing jealousy and rising anger are contrasted to Desdemona's meek Christian piety and innocent wonder about his accusations with humility. The scene bursts out in violent verbal aggression with a racing cumulative list of bawdy terms. The early $\mathrm{G}$ and $\mathrm{P}$ versions show some mitigation (or hesitation in the manuscript version of the translation) in accordance with the current literary fashions, while the later translations, like S1987, take liberties in rendering the bawdy terms by modernising the diction.

Our text sample is concise but sufficient to show some tendencies and diachronic developments in translation strategies. During our study, we became aware of several pitfalls, as languages are in a constant process of change and development. The time span between the early and the late translations is long enough for semantic changes to come about and they can pose a major problem for interpreting shifts in meaning, particularly if and when irony and sarcasm are involved. Societies develop and the means vary in expressing subtle nuances in changes of interpersonal relations (see above).

Our analysis proves that contrastive pragmatic study is possible even in a diachronic perspective, which has not received much attention. Our task in this paper has been to illustrate the interface between historical pragmatics and contrastive pragmatics. Therefore, we have focused on politeness with its culture-bound repertoires and address term systems as they are particularly sensitive to societal changes. This exercise proves that it is possible to gain insights into cultural aspects of literary interpretation by applying historical pragmatic analysis and contextualising pragmatic features of language use. The language selection of our study with German, Swedish, Polish and Finnish revealed clear distinctions in translation strategies. The scope of our study did not allow space to go deeper into the field of translation studies. ${ }^{36}$ The field

35 Cf. Othello's description of his love to Desdemona "O my soul's joy" (ii.i.176).

36 E.g. aspects of dramatic performance and translation variants is clearly outside the present scope. 
at the crossroads that we have charted here is extremely rich with plenty of opportunities for original studies.

\section{References}

\section{Primary Sources}

Othello, A New Variorum Edition of Shakespeare. 1983. Ed. by Horace Howard Furness. New York: Dover Publications.

Shakespeare, William. 1632. Second Folio. Mr. William Shakespeare Comedies, histories and tragedies. Published according to the true originall copies. The second impression. Printed by Tho. Cotes for Robert Allot. London: Smethwick, J., Aspley, W., Hawkins, Richard, and Meighan, Richard. At: https://internetshakespeare.uvic.ca/Library/ facsimile/overview/book/F2.html.

The Riverside Shakespeare. 1973. Ed. by Evans, G. Blakemore. Boston: Houghton Miffin Company.

\section{Translations Used}

\section{German}

Shakespeare, William. Othello. 1832. Tragödie (um 16o3). Übersetzung: Wolf Heinrich Graf von Baudissin. At: https://www.textlog.de/shakespeare-othello.html.

Shakespeare, William. 1999. Othello. Zweisprachige Ausgabe. Neu übersetzt und mit Anmerkungen versehen von Frank Günther. München: Deutscher Taschenbuch Verlag.

\section{Polish}

Dzieta dramatyczne Williama Shakespeare (Szekspira) w dwunastu tomach. Tom V. Otello. 1895. Tłumaczenie Leon Ulrich. Kraków: Gebethner i Wolff.

Hołowiński, Ignacy. 1834. Otello, albo Murzyn z Wenecyi Szekspira. Rękopis. Kraków: Biblioteka Jagiellońska. At: https://polona.pl/item/otello-albo-murzyn -z-wenecyi-shakespeara,MTAıMTgoNzkz/74/\#info:metadata.

Shakespeare, William. 2002. Otello, Maur Wenecki. Przełożył Stanisław Barańczak. Kraków: Wydawnictwo Znak.

Szekspir. 1880. Otello. Tragedya w pięciu Aktach. Tłumaczył Szczęsny Kluczycki. Warszawa: Wydawnictwo Dzieł Tanich A. Wiślickiego.

Szekspir. 1925. Otello. Przedład Józefa Paszkowskiego. Lwów; Złoczów: W. Zukerkandel. At: https://polona.pl/item/otello,MTczNDI2NDU/6/\#item.

Szekspir, Wiliam. 1956. Otello. Przełożyła Krystyna Berwińska. Warszawa: Państwowy Instytut Wydawniczy. 


\section{Swedish}

Shakespeares dramatiska arbeten: Tragedier. Översatta av Carl August Hagberg. [1850] 1950. Sjunde bandet: Othello, Konung Lear. Upplaga reviderat as Nils Molin. Lund: G.W.K. Gleerups förlag.

William Shakespeare Othello. I svensk översättning as Mats Hulden \& Lars Hulden. 1987. Stockholm: Ordfront.

\section{Finnish}

Shakespeare: Othello. 1884. Suom. Cajander. (No publication information.)

Shakespeare'n draamoja. II. Othello. [1884] 1925. Suomentanut P. Cajander. 4th edn. Helsinki: Suomalaisen Kirjallisuuden Seuran Kirjapaino oy.

William Shakespear, Othello: Venetsia mauri. 2003. Suomentanut Matti Rossi. Helsinki: Werner Söderström osakeyhtiö.

William Shakespearen suuret dreamat II. Hamlet, Othello. 1915. Suomentanut Yrjö Jylhä. Helsinki: Otava.

\section{Secondary Sources}

Aijmer, Karin (ed.). 20o9. Contrastive Pragmatics. Special issue of Languages in Contrast 9(1).

Aijmer, Karin, Juliane House, Dániel Z. Kádár, and Hong Liu (eds.). 202O. Contrastive Pragmatics. Inaugural issue 1(1).

Archer, Dawn. 2018. Context and historical (socio)pragmatics twenty years on. Journal of Historical Pragmatics 18(1): 315-336. 10.1075/jhp.oooo8.arc.

Arct, Michał. 1916. M. Arcta Stownik Ilustrowany Jezzyka Polskiego. Warszawa: Drukarnia M. Arcta.

Arnovick, Lesley K. 1999. Diachronic Pragmatics. Seven Case Studies in English Illocutionary Development (Pragmatics \& Beyond New Series 68). Amsterdam: John Benjamins.

Baumgarten, Nicole, Inke Du Bois and Juliane House (eds.). 2012. Subjectivity in Language and Discourse. Leiden: Brill.

Bax, Marcel (ed.). 2003. Ritual Language Behaviour. Special Issue of Journal of Historical Pragmatics 4(2).

Bax, Marcel. 2010. Epistolary presentation rituals: Face-work, politeness, and ritual display in Early Modern Dutch letter-writing. In: Jonathan Culpeper, and Dániel Z. Kádár, Historical (Im)politeness. Frankfurt am Main: Peter Lang, 37-85.

Biber, Douglas. 2004. Historical patterns for the grammatical marking of stance: A cross-register comparison. Journal of Historical Pragmatics 5(1): 107-136.

Biber, Douglas, and Edward Finegan. 1997. Diachronic relations among speech-based and written registers in English. In: Terttu Nevalainen, and Lena Kahlas-Tarkka 
(eds.), To Explain the Present: Studies in the Changing English Language in Honour of Matti Rissanen. Helsinki: Société Néophilologique, 253-275.

Blommaert, Jan. 2005. Discourse:A Critical Introduction. (KeyTopics in Sociolinguistics). Cambridge: Cambridge University Press. doi:10.1017/CBO9780511610295.004.

Blommaert, Jan, and Małgorzata Szabla. 2018. Does context really collapse in social media interaction? Applied Linguistics Review 9(4): 1-29.

Blum-Kulka, Shoshana, Juliane House, and Gabriele Kasper (eds.). 1989. Cross-Cultural Pragmatics: Requests and Apologies. Norwood, N.J.: Ablex.

Braun, Friederike. 1988. Terms of Address. Problems of Patterns and Usage in Various Languages and Cultures. Berlin/New York: Mouton de Gruyter.

Busse, Beatrix, and Ulrich Busse. 2010. Pragmaphilology: Shakespeare. In: Andreas H. Jucker and Irma Taavitsainen (eds.), Historical Pragmatics (Handbooks of Pragmatics 8). Berlin/New York: Mouton de Gruyter, 246-281.

Busse, Beatrix, and Ulrich Busse. 2012. Early Modern English:Thelanguage of Shakespeare. In: Alexander Bergs, and Laurel Brinton (eds.), English Historical Linguistics: An International Handbook. Volume 1. Berlin, New York: Mouton de Gruyter, 8०8-826.

Coulmas, Florian (ed.). 1981. Conversational Routine. Explorations Standardized Communication Situations and Prepatterned Speech. The Hague: Mouton Publishers.

Crashaw, Robert. 2017. Determinacy, distance and intensity in intercultural communication: An emancipatory approach. In: Istvan Kecskes and Stavros Assimakopoulus (eds.), Issues in Intercultural Pragmatics. Amsterdam/Philadelphia:John Benjamins, $19-52$.

Culpeper, Jonathan, and Merja Kytö. 2010. Early Modern English Dialogues: Spoken Interaction as Writing. Cambridge: Cambridge University Press.

Culpeper, Jonathan, and Jane Demmen. 2011. Nineteenth-century English politeness: Negative politeness, conventional indirect requests and the rise of the individual self. Journal of Historical Pragmatics 12(1-2): 49-81.

Culpeper, Jonathan, and Daniel Z. Kádár (eds.). 2010. Historical (Im)politeness. Bern: Peter Lang.

Denizot, Camillle, and Olga Spevak (eds.). 2017. Pragmatic Approaches to Latin and Ancient Greek. Amsterdam: John Benjamins Publishing Company.

Deringer, Lisa, Volker Gast, Florian Haas and Olga Rudolf. 2015. Impersonal uses of the second person singular and generalized empathy: An exploratory corpus study of English, German and Russian. In: Laure Gardelle and Sandrine Sorlin (eds.), The Pragmatics of Personal Pronouns. Berlin: Mouton de Gruyter, 331-334.

Duranti, Alessandro, and Charles Goodwin (eds.). 1992. Rethinking Context. Language as an Interactive Phenomenon. Cambridge: Cambridge University Press.

Fedriani, Chiara, and Andrea Sansò (eds.). 2017. Pragmatic Markers, Discourse Markers and Modal Particles: New Perspectives. Amsterdam: John Benjamins. 
Gleason, Henry A. 1968. Contrastive analysis in discourse structure. In: James E. Alatis (ed.), Report of the 19th Annual Round Table Meeting on Linguistics and Language Studies. Washington, D.C.: Georgetown University Press, 39-63.

Gunnarsson, Britt-Louise. 2001. Expressing criticism and evaluation during three centuries. Journal of Historical Pragmatics 2(1): 115-139.

Held, Gudrun. 2010. “Suplica la mia parvidade ...”. Journal of Historical Pragmatics 11(2): 194-218.

Honigmann, E.A.J. 1996. The Texts of Othello and Shakespearean Revision. London: Routledge.

House, Juliane. 1985. Contrastive discourse analysis and universals in language use. Papers and Studies in Contrastive Linguistics 20: $5^{-14}$.

House, Juliane. 2006. Communicative styles in English and German. European Journal of English Studies 10(3): 249-267.

House, Juliane. 2015. Translation Quality Assessment:Past and Present. London: Routledge.

House, Juliane. 2016. Translation as Communication across Languages and Cultures. London: Routledge.

Huang, Yan. 2007. Pragmatics. Oxford: Oxford University Press.

Jacobs, Andreas, and Andreas H. Jucker. 1995. The historical perspective in pragmatics. In: Andreas H. Jucker (ed.), Historical pragmatics. Pragmatic Developments in the History of English. Amsterdam/Philadelphia: John Benjamins, 3-33.

Jenkins, Harold. 1955. The Relation between the Second Quarto and the Folio Text of "Hamlet". Studies in Bibliography 7: 69-83.

Jucker, Andreas H. (ed.). 1995. Historical pragmatics. Pragmatic Developments in the History of English. Amsterdam/Philadelphia: John Benjamins.

Jucker, Andreas H. 200o. English historical pragmatics: Problems of data and methodology. In: Gabriella Di Martino and Maria Lima (eds.), English Diachronic Pragmatics. Naples: CUEN, $17-55$.

Jucker, Andreas. 2004. Contrastive analysis across time: Issues in historical dialogue analysis. In: Dominique Willems, Bart Defrancq, Timothy Colleman, and Dirk Noël (eds.), Contrastive Analysis in Language: Identifying Linguistic Units of Comparison. Basingstoke: Palgrave Macmillan, 197-212.

Jucker, Andreas H. 2008. Historical pragmatics. Language and Linguistics Compass 2(5): 894-9o6.

Jucker, Andreas H., and Irma Taavitsainen. 2000. Diachronic speech act analysis: Insults from flyting to flaming. Journal of Historical Pragmatics 1(1): 67-95.

Jucker, Andreas H. 2020. Politeness in the History of English: From the Middle Ages to the Present Day. Cambridge: Cambridge University Press.

Kádár, Dániel Z. 2012. Historical Chinese politeness and rhetoric. A case study of epistolary refusals. Journal of Politeness Research 8: 93-110. DOI 10.1515/pr-2012-0oo6. 
Kádár, Dániel Z. 2007. Terms of (Im)politeness: On the Communicational Properties of Traditional Chinese (Im)polite Terms of Address. Budapest: University of Budapest Press.

Kádár, Dániel Z., and Sara Mills (eds.). 2011. Politeness in East Asia. Theory and Practice. Cambridge: Cambridge University Press.

Kádár, Dániel Z., and Francesca Bargiella-Chiappini. 2011. Introduction: Politeness research in and across cultures. In: Francesca Bargiella-Chiappini and Dániel Z. Kádár (eds.), Politeness across Cultures. Basingstroke: Palgrave Macmillan, 1-14.

Kádár, Daniel Z., and Juliane House. 2019. Ritual frames. A contrastive pragmatic approach. Pragmatics. DOI 10.1075/prag.19018.kad.

Keinänen, Nely. 2021fc. The role of Hamlet in Finnish-Nation-Building. 1879-84. In: Mártha Minier and Lily Kahn (eds.), Hamlet Translations: Prisms of Cultural Encounters Across the Globe. Oxford: Legenda.

King, Jeremy. 2010. Pleas from the New World: The structure of directive head acts in Colonial Spanish familiar letters. Journal of Historical Pragmatics 11(2): $250-276$.

Koch, Peter, and Wulf Oesterreicher. 1985. Sprache der Nähe - Sprache der Distanz: Mündlichkeit und Schriftlichkeit im Spannungsfeld von Sprachtheorie und Sprachgeschichte. Romanistisches Jahrbuch 36: 15-43.

Kohnen, Thomas. 2008. Tracing directives through text and time: Towards a methodology of a corpus-based diachronic speech-act analysis. In: Andreas H. Jucker and Irma Taavitsainen (eds.), Speech Acts in the History of English. Amsterdam: John Benjamins, 295-310.

Kopytko, Roman. 1995. Linguistic politeness strategies in Shakespeare's plays. In: Andreas H. Jucker (ed.), Historical Pragmatics. Pragmatic Developments in the History of English (Pragmatics \& Beyond New Series 35). Amsterdam/Philadelphia: John Benjamins, 515-540.

Kranich, Svenja. 2016. Contrastive Pragmatics and Translation. (Pragmatics \& Beyond News Series Volume 261). Amsterdam: John Benjamins.

Labov, William. 1972. Language in the Inner City. Studies in Black English Vernacular. Philadelphia: University of Pennsylvania Press.

Labov, William. 1994. Principles of Linguistic Change. Volume 1: Internal Factors. Oxford: Blackwell.

Lass, Roger. 1997. Historical Linguistics and Language Change (Cambridge Studies in Linguistics). Cambridge: Cambridge University Press.

Mey, Jacob L. 1998. Pragmatics. In: Jacob L. Mey (ed.), Concise Encyclopedia of Pragmatics. Amsterdam: Elsevier, 716-734.

Murphy, S. 2015. I will proclaim myself what I am: Corpus stylistics and the language of Shakespeare's soliloquies. Language and Literature 24(4), 338-354. 
Ogiermann, Eva. 2009. Politeness and in-directness across cultures: A comparison of English, German, Polish and Russian requests. Journal of Politeness Research 5(2): 189-216.

Ogiermann, Eva and Spyridoula Bella. 2020. An interlanguage study of request perspective: Evidence from German, Greek, Polish and Russian Learners of English. Contrastive Pragmatics 1(2): 180-209.

Palander-Collin, Minna. 20o9. Variation and change in patterns of self-reference in early English correspondence. In: Jonathan Culpeper (ed.), Historical sociopragmatics. Special issue of Journal of Historical Pragmatics 10: 26o-285.

Pan, Yuling, and Dániel Z. Kádár. 2011. Politeness in Historical and Contemporary Chinese. London and New York: Continuum.

Risselada, Rodie. 1993. Imperatives and Other Directive Expressions in Latin: A Study in the Pragmatics of a Dead Language. Amsterdam: J.C. Gieben.

Rühlemann, Christoph, and Karin Aijmer. 2015. Corpus pragmatics: Laying the foundations. In: Karin Aijmer, and Christoph Rühlemann (eds.), A Handbook of Corpus Pragmatics: Exploring Speaker and Writer Meaning in Computer Corpora. Cambridge: Cambridge University Press, 1-26.

Salager-Meyer, Françoise, and Nahirana Zambrano. 2001. The bittersweet rhetoric of controversiality in nineteenth- and twentieth-century French and English medical literature. Journal of Historical Pragmatics 2(1): 141-174.

Schlieben-Lange, Brigitte. 1983. Traditionen des Sprechens. Elemente einer pragmatischen Sprachgeschichts-schreibung. Stuttgart: Kohlhammer.

Schrott, Angela. 200o. Quí los podrié contar? Interrogative acts in the Cantar de mio Cid: Some examples from Old Spanish on asking questions. Journal of Historical Pragmatics 1(2): 263-300.

Scollon, Ron, and Suzanne W. Scollon. 2001. Intercultural Communication: A Discourse Approach. 2nd ed. Oxford: Blackwell.

Sell, Roger D. 1985a. Tellability and politeness in 'The Miller's Tale': First steps in literary pragmatics. English Studies: A Journal of English Language and Literature 66(6): 496-512. D OI: 10.108o/oo138388508598414.

Sell, Roger D. 1985 b. Politeness in Chaucer: Suggestions towards a methodology for pragmatic stylistics. Studia Neophilologica 57: 175-185. DoI: 10.1080/oo393278508587918.

Stein, Dieter. 1985. Perspectives on historical pragmatics. Folia Linguistica Historica 6(2): $347-355$.

Taavitsainen, Irma. 1995. Interjections in Early Modern English: From imitation of spoken to conventions of written language. In Andreas H. Jucker (ed.), Historical pragmatics: Pragmatic developments in the history of English, 439-465. Amsterdam/ Philadelphia: John Benjamins. 
Taavitsainen, Irma. 2016. Address Terms. In: Wendy Anderson, Ellen Bramwell, and Carole Hough (eds.), Mapping English Metaphor Through Time. 26o-279. Oxford: Oxford University Press.

Taavitsainen, Irma, and Andreas H. Jucker. 2010. Trends and developments in historical pragmatics. In Andreas H. Jucker \& Irma Taavitsainen (eds.), Historical Pragmatics (Handbooks of Pragmatics 8). Berlin/New York: Mouton de Gruyter, 3-30.

Taavitsainen, Irma, and Andreas H. Jucker. 2007. Speech acts and speech act verbs in the history of English. In: Susan M. Fitzmaurice, and Irma Taavitsainen (eds.). Methods in Historical Pragmatics. Berlin: Mouton de Gruyter, 107-138.

Taavitsainen, Irma, Andreas H. Jucker, and Jukka Tuominen. 2014. Diachronic Corpus Pragmatics. Amsterdam: Benjamins.

Tagg, Caroline, and Mel Evans. 2020. Historicising the Digital: English language practices in new and old media. Mouton de Gruyter.

Tiisala, Sija 2004. Power and politeness: Languages and salutation formulas in correspondence between Sweden and the German Hanse. Journal of Historical Pragmatics 5(2): 193-207.

Traugott, Elizabeth Closs. 2008. The state of English language studies: A linguistic perspective. In: Marianne Thormählen (ed.), English Now. Selected Papers from the 2oth IAUPE Conference in Lund 2007. Lund: Lund Studies in English, 199-225.

Traugott, Elizabeth Closs. 2019. Whither historical pragmatics? A cognitively-oriented perspective. Journal of Pragmatics 145: 25-30. DoI: 10.1016/j.pragma.2019.01.0o6.

Valle, Ellen. 2004. 'The pleasure of receiving your favour': The colonial exchange in eigh-teenth-century natural history. Journal of Historical Pragmatics 5(2): 313-336.

Van Dijk, Teun A. 2008. Discourse and Context. A Sociocognitive Approach. Cambridge: CUP.

Van Oort, Richard. 2016. Shakespeare's Big Men:Tragedy and the Problem of Resentment. Toronto: University of Toronto Press.

Verschueren, Jef. 1999. Understanding Pragmatics. London: Arnold.

Watts, Richard J. 1999. Politeness. Cambridge: Cambridge University Press.

Włodarczyk, Matylda. 2007. Pragmatic Aspects of Reported Speech. The Case of Early Modern English Courtroom Discourse. Frankfurt am Main: Peter Lang.

Włodarczyk, Matylda. 2013. Self-reference and ego involvement in the 1820 Settler petition as a leaking genre. In: Marijke J. van der Wal, and Gijsbert Rutten (eds.), Touching the Past. Studies in the Historical Sociolinguistics of Ego-documents. Amsterdam/Philadephia: John Benjamins, 201-224. 